\title{
Physical properties of Rhus tripartium (Ucria) Grande fruits and seeds, indigenous of drylands Tunisia
}

\author{
Zouaoui Refka ${ }^{12^{*}}$, Ksontini Mustapha ${ }^{1}$ and Ferchichi Ali $^{2}$ \\ ${ }^{I}$ Ecology and Sylvo-pastoral Improvement Laboratory, National Research Institute of Rural Engineering, Water \\ and Forests (INRGREF), BP 10 Ariana 2080, Tunisia \\ ${ }^{2}$ Arid and Oases Cropping Laboratory, Arid Area Institute (IRA), Medenine 4119, Tunisia
}

\begin{abstract}
In this study, some physical properties of fruit and seeds of $R$. tripartitum were determined in different provenances to know this species and see their morphological variations in arid regions of Tunisia. A highly significant difference between and within the site $(0,000<0,05 \%)$ was found on the results of the ANOVA. Dimensions fruits vary from 4,892 (BH) to 6,705 (MM) mm long; 4,020 (BH) to 5,486 (MM) mm wide and 3,745 (BKH) to 3,56 (BH) thick. Sphericity ( $\phi$ fr ) and area (Sfr) range from 0,842 (BH) 0,020 (MM) and 53,303 (BH) to 75,636 (MM ) $\mathrm{mm}^{2}$ respectively. Fruits from Matmata are heavier, while Djerba presented the lighter fruits. For seed sizes ranging from 3,750 (DJ) to 4,449 (MM) mm long, 2,676 (DJ) to 3,214 (MM) $\mathrm{mm}$ wide (lsmc) and 1,646 mm (BKH) to 0,970 (DJ) mm thickness (Esmc). Sphericity ( $\phi s m c)$ and area (Ssmc) range from 0,629 (BKH) to 0,569(DJ) and 24,416 (BKH) to 14,267 (DJ) $\mathrm{mm}^{2}$ respectively. Drupes and seeds of $R$. tripartitum present the most important dimensions to mountain resorts (Matmata and Beni khedache) implying that this species favors high altitudes.
\end{abstract}

Keywords: Rhus tripartitum (Ucria) Grande ; Physical properties; Tunisia; mature

\section{Introduction}

Sumac (Rhus tripartitum (Ucria) Grande), belonging to the Anacardiacea family, is a small tree or shrub twigs, very spiny, toothed leaves glaucous.

This is a pastoral, medicinal and food species. It to an anti-erosive role if reforestation troughs. It grows in Mediterranean countries, North Africa and in the Middle East.

In Tunisia, it colonizes the dorsal, central and southern.

The combined action anthropic and climatic factors caused a progressive threat of plant heritage in particular Rhus tripartitum.

The objective of this work is to determine the physical properties of $R$. tripartitum fruit and seeds in different provenances in southern Tunisia, to know this species and see their morphological variations in arid regions of Tunisia.

Fruits play a role in providing nutritious minerals and vitamins (Serville, 1984). These elements are essential to the proper functioning of the body and are among the main sources of micronutrients to food balance in the body. Minerals are of interest because of their pro -oxidant activity and benefits to human health (Parcesio et al., 1995; Pershern et al., 1995; Pala et al. , 1996; Alphan et al., 1996) . Various dysfunctions and diseases due to deficiencies in micronutrients, especially minerals (calcium, potassium, magnesium) and trace elements (iron, copper ) (Besançon, 1990). The specificity of a nutritious fruit is related to its composition depends on the species, variety, degree of maturity and other factors of environment and conservation. Tunisia has made significant plant species of trees and fruit bushes whose majority is not highlighted. Their production is locally underexploited despite interesting food characteristics. Of these, some have the feature to adapt to different climates, especially in arid and semi arid areas. We chose to study unconventional fruits of Rhus tripartitum and their seeds. Their consumption is seasonal and nutritional values are not yet known. We do not have to evaluate their potential in mineral content and biochemical elements. Minerals are inorganic substances that are essential for the proper functioning of metabolism. They can be classified into macronutrients (sodium, potassium, nitrogen, calcium, magnesium and phosphorus) and micro elements (trace elements) as a function of their concentrations $(<10 \mathrm{mmol} / \mathrm{kg}$ ) in the material dry (Hopkins, 2003). We therefore proceeded to determine the dimensional and geometric properties of fruit and seeds of this spontaneous and unconventional species. We spent the following mineral extraction and see some biochemical composition of fruit pulp and seeds in order to judge the appropriateness of the use as additives in the food or pharmaceutical industries. 


\section{Materials}

\section{Materials And Methods}

The study was carried on the fruits and seeds of Rhus tripartitum (Fig.1.) Collected from four sources in arid regions of southern Tunisia: Beni Khedache (BKH), Djerba (DJ), Bou Hedma (BH) and Matmata (MM)) (Table.1).

Table1. Bioclimatic characteristics of Rhus tripartitum stations in arid areas of southern Tunisia

\begin{tabular}{|c|c|c|c|c|c|}
\hline Stations & Sites & Bioclimats & Altitude & Latitude & Sea level (m) \\
\hline Bou Hedma Parc & Sidi bouzid & arid superior & $32606527 \mathrm{E}$ & $4078522 \mathrm{~N}$ & 23 \\
\hline Djerba & Medenine & $\begin{array}{l}\text { Aride } \\
\text { inferior }\end{array}$ & $32666784 \mathrm{E}$ & $3744115 \mathrm{~N}$ & 12 \\
\hline Beni Khedache & Medenine & $\begin{array}{l}\text { Aride } \\
\text { inferior }\end{array}$ & $32618759 \mathrm{E}$ & $3682139 \mathrm{~N}$ & 340 \\
\hline Matmata & Gabes & $\begin{array}{l}\text { Saharan } \\
\text { superior }\end{array}$ & $32591720 \mathrm{E}$ & $3710218 \mathrm{~N}$ & 428 \\
\hline
\end{tabular}

Drupes were collected in the field at maturity (February). The degree of maturation was visually based on their dimensions and colors. The seeds were obtained after drying drupes at ambient air.

\section{Methods}

The physical properties were determined by the following methods: Linear dimensions, i.e. length (L), width (W) and thickness (T) (Fig.1), were measured by using a digital caliper with a sensitivity of 0,01 $\mathrm{mm}$.
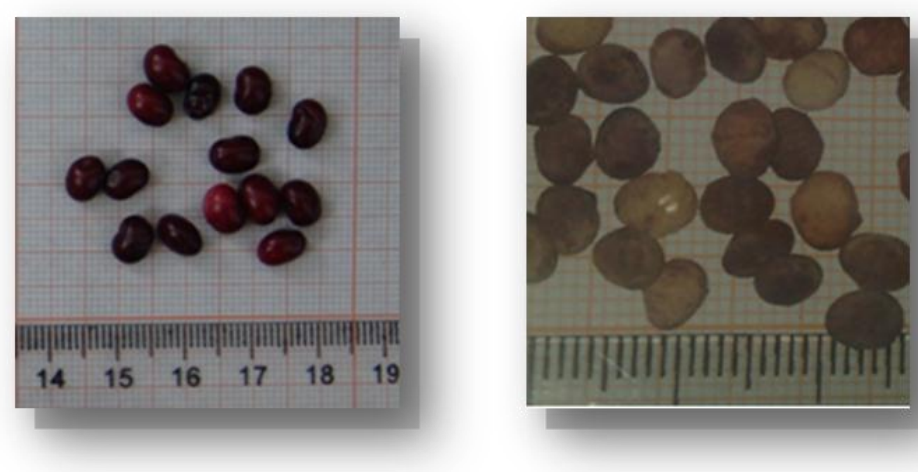

(b)

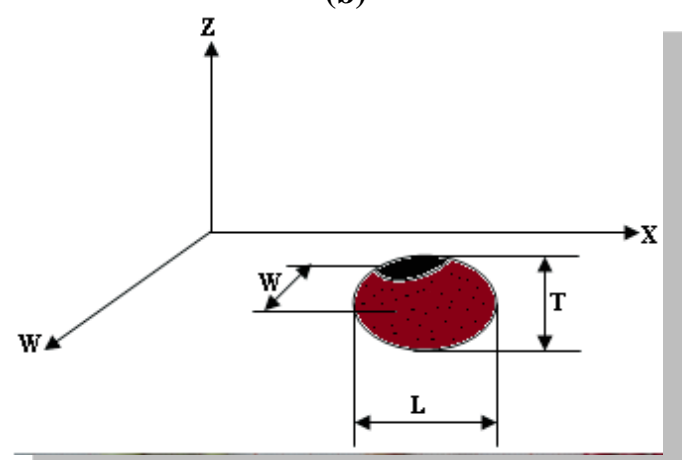

(c)

Figure 1. Fruits (a) and seeds (b) of Rhus tripartitum (picture of the author); (c) Axis and three major dimensions of fruit

Samples are taken at random. The average weight of 100 fruits is measured with a precision balance.

Arithmetic $\left(D_{a}\right)$ and geometric $\left(D_{g}\right)$ diameter of fruits and seeds were calculated by using the following relationship (Olajide et Igbeka, 2003) :

$$
\begin{gathered}
\mathbf{D a}=\frac{\mathbf{L} * \mathbf{W} * \mathbf{T}}{\mathbf{3}} \\
\mathbf{D g}=(\mathbf{L} * \mathbf{W} * \mathbf{T})^{\mathbf{1 / 3}}
\end{gathered}
$$


With :

$\mathrm{D}_{\mathrm{a}}=$ arithmetic diameter $(\mathrm{mm})$

$\mathrm{D}_{\mathrm{g}}=$ Geometric diameter $(\mathrm{mm})$

$\mathrm{L}=$ Length $(\mathrm{mm})$

$\mathrm{W}=$ Width $(\mathrm{mm})$

$\mathrm{T}=$ Thickness $(\mathrm{mm})$

Sphericity (\%) :

$$
\boldsymbol{\phi}=\frac{\mathbf{D g}}{\mathbf{L}}(\%) \text { (Mirzabe et al., 2013) }
$$

Surface area $\left(\mathrm{mm}^{2}\right)$ samples which are similar to the sphere: obtained by the equation given by Nazari Galedar and $a l .$, (2008) ; Ozcan and Haciseferogullari (2004).

$$
\mathrm{S}=\pi * \mathrm{Dg}^{2}
$$

Volume V $\left(\mathrm{mm}^{3}\right)$ : determined by par Ozcan and Haciseferogullari (2004), Kibar and Öztürk (2008).

$$
\mathbf{V}=\frac{\pi * \mathbf{B} * \mathbf{L}^{2}}{\mathbf{6}(\mathbf{2} \mathbf{L}-\mathbf{B})} \quad \text { with } \mathbf{B}=(\mathbf{W} * \mathbf{T})^{\mathbf{0 , 5}}
$$

\section{-Physical properties of Rhus tripartitum}

\section{Results}

Physical properties of Rhus tripartitum fruits and seeds were given in Table 2.

Table 2. Physical properties of Rhus tripartium fruits and seeds (Length (Lfr- Lsmc), Width (lfr- 1smc) and Thickness (Efr- Esmc), arithmetic diameter (Dgfr-Dgsmc), geometric diameter (Dafr- Dasmc), Sphericity ( $\phi$ fr-

\begin{tabular}{|c|c|c|c|c|c|c|}
\hline Organes & Caractères & ВКН & DJ & BH & MM & $\begin{array}{c}\text { Significant } \\
\text { level }\end{array}$ \\
\hline \multirow{9}{*}{ Fruit } & Length (mm) (Lfr) & $6,09 \pm 0,2^{\mathrm{b}}$ & $5,88 \pm 0,57^{\mathrm{b}}$ & $4,89 \pm 0,1^{\mathrm{a}}$ & $6,71 \pm 0,26^{\mathrm{c}}$ & $* * *$ \\
\hline & Width (mm) (lfr) & $4,80 \pm 0,15^{\mathrm{b}}$ & $4,63 \pm 0,54^{\mathrm{ab}}$ & $4,02 \pm 0,23^{\mathrm{a}}$ & $5,49 \pm 0,4^{\mathrm{c}}$ & $* * *$ \\
\hline & $\begin{array}{c}\text { Thickness (mm) } \\
\text { (Efr) }\end{array}$ & $3,74 \pm 0,12^{b}$ & $3,57 \pm 0,26^{\mathrm{ab}}$ & $3,56 \pm 0,26^{\mathrm{ab}}$ & $3,36 \pm 0,35^{\mathrm{a}}$ & $*$ \\
\hline & $\begin{array}{c}\text { Arithmetic diameter } \\
\text { (Dafr) }\end{array}$ & $36,48 \pm 1,48^{b}$ & $32,89 \pm 7,35^{\mathrm{ab}}$ & $23,35 \pm 2,27^{\mathrm{a}}$ & $40,50 \pm 4,66^{\mathrm{b}}$ & $* * *$ \\
\hline & $\begin{array}{c}\text { Geometric diameter } \\
\text { (Dgfr) }\end{array}$ & $4,78 \pm 0,06^{\mathrm{b}}$ & $4,59 \pm 0,39^{a b}$ & $4,12 \pm 0,14^{\mathrm{a}}$ & $4,91 \pm 0,2^{b}$ & $* * *$ \\
\hline & Volume $\left(\mathrm{mm}^{3}\right)(\mathrm{Vfr})$ & $655,35 \pm 76,49^{b}$ & $591,63 \pm 193,1^{\mathrm{b}}$ & $284,08 \pm 21,02^{\mathrm{a}}$ & $912,65 \pm 121,87^{\mathrm{c}}$ & $* * *$ \\
\hline & Mass (g) P100fr & $6,39 \pm 0,81^{\mathrm{a}}$ & $5,42 \pm 0,91^{\mathrm{a}}$ & $6,16 \pm 0,98^{\mathrm{a}}$ & $8,50 \pm 0,3^{b}$ & $* * *$ \\
\hline & $\begin{array}{c}\text { Surface area }\left(\mathrm{mm}^{2}\right) \\
(\text { Sfr })\end{array}$ & $71,83 \pm 1,93^{\mathrm{b}}$ & $66,63 \pm 10,92^{\mathrm{ab}}$ & $53,30 \pm 3,58^{\mathrm{a}}$ & $75,64 \pm 1,79^{\mathrm{c}}$ & $* * *$ \\
\hline & Sphericity (\%) ( $\phi f r)$ & $0,79 \pm 0,02^{\mathrm{a}}$ & $0,78 \pm 0,02^{\mathrm{a}}$ & $0,84 \pm 0,03^{\mathrm{b}}$ & $0,75 \pm 0,05^{\mathrm{a}}$ & $* * *$ \\
\hline \multirow{9}{*}{ Seed } & Length (mm) (Lsmc) & $4,44 \pm 0,32^{\mathrm{a}}$ & $3,75 \pm 0,26^{\mathrm{a}}$ & $4,06 \pm 0,10^{\mathrm{ab}}$ & $4,45 \pm 0,14^{b}$ & $* * *$ \\
\hline & Width (mm) (lsmc) & $2,98 \pm 0,23^{\mathrm{ab}}$ & $2,68 \pm 0,18^{\mathrm{a}}$ & $2,75 \pm 0,19^{\mathrm{a}}$ & $3,21 \pm 0,13^{\mathrm{b}}$ & $* * *$ \\
\hline & $\begin{array}{c}\text { Thickness (mm) } \\
\text { (Esmc) }\end{array}$ & $1,65 \pm 0,18^{\mathrm{c}}$ & $0,97 \pm 0,15^{\mathrm{a}}$ & $1,36 \pm 0,10^{\mathrm{b}}$ & $1,32 \pm 0,21^{\mathrm{b}}$ & $* * *$ \\
\hline & $\begin{array}{c}\text { arithmetic diameter } \\
\text { (Dasmc) }\end{array}$ & $7,25 \pm 1^{\mathrm{c}}$ & $3,25 \pm 0,62^{\mathrm{a}}$ & $5,10 \pm 0,79^{b}$ & $6,31 \pm 1,08^{\mathrm{bc}}$ & $* * *$ \\
\hline & $\begin{array}{c}\text { Geometric diameter } \\
\text { (Dgsmc) }\end{array}$ & $2,79 \pm 0,14^{\mathrm{c}}$ & $2,13 \pm 0,14^{\mathrm{a}}$ & $2,48 \pm 0,12^{\mathrm{b}}$ & $2,66 \pm 0,16^{\mathrm{bc}}$ & $* * *$ \\
\hline & Volume $\left(\mathrm{mm}^{3}\right)$ Vsmc & $154,49 \pm 35,57^{\mathrm{c}}$ & $70,75 \pm 16,54^{\mathrm{a}}$ & $103,85 \pm 12,72^{b}$ & $145,88 \pm 16,42^{\mathrm{c}}$ & $* * *$ \\
\hline & Mass (g) P100 (smc) & $4,37 \pm 1,16^{\mathrm{a}}$ & $4,09 \pm 0,76^{\mathrm{a}}$ & $5,36 \pm 1,44^{\mathrm{b}}$ & $5,73 \pm 0,99^{\mathrm{b}}$ & $* *$ \\
\hline & $\begin{array}{c}\text { Surface area }\left(\mathrm{mm}^{2}\right) \\
\text { Ssmc }\end{array}$ & $24,42 \pm 2,35^{\mathrm{c}}$ & $14,27 \pm 1,82^{\mathrm{a}}$ & $19,31 \pm 1,96^{\mathrm{b}}$ & $22,24 \pm 2,58^{\mathrm{bc}}$ & $* * *$ \\
\hline & $\begin{array}{c}\text { Sphericity (\%) } \\
(\phi s m c)\end{array}$ & $0,63 \pm 0,03^{b}$ & $0,57 \pm 0,03^{\mathrm{a}}$ & $0,61 \pm 0,02^{\mathrm{ab}}$ & $0,60 \pm 0,03^{\mathrm{ab}}$ & $* *$ \\
\hline
\end{tabular}
$\phi s m c)$, Surface area (Sfr- Ssmc), volume (Vfr- Vsmc) and Mass $\left(\mathrm{P}_{100}\right.$ Fr- $\mathrm{P}_{100}$ smc) for different origins of Tunisian south

$* *, * * *$ : significant levels at $1 \%, 0.1 \%$, respectively

a,b,c,d: letters indicate the statistical difference in rows. 
The fruit were between 4,770 and 6,920 $\mathrm{mm}$ in length, between 3,63 and 6,1 $\mathrm{mm}$ in width and between 3,080 and 4,240 $\mathrm{mm} \mathrm{mm}$ in thickness. The biggest dimensions are recorded at the origin of Matmata compared to others provenances. The fruits of Bou Hedma were smaller. While mean fruit length was 5,864 mm, fruit width was $4,734 \mathrm{~mm}$ and thickness was 3,560 $\mathrm{mm}$. Mean mass of the 100 fruit was $6,619 \mathrm{~g}$. The range of variation of the average varies between 4.370 and $9.060 \mathrm{~g}$. The fruits of Matmata are heaviest while Djerba presented the lighter fruits.

Sphericity is an expression of a shape of a solid relative to that of a sphere of the same volume while the aspect ratio relates the width to the length of the fruit which is an indicative of its tendency toward being oblong in shape.

The range of variation of average sphericity of the fruits varied between 0.690 and 0.920 which mean fruit sphericity was 0.791. Geometric and arithmetic diameter Fruit were between 3,930 - 5,320 mm and 20,26 $50,29 \mathrm{~mm}$, respectively. The surface area ranged between 48,540 and $88,990 \mathrm{~mm}^{2}$. Mean fruit volume was $599.695 \mathrm{~mm}^{3}$.

The seed were between 3,310 and 4,91 mm in length, between 2,430 and 3,340 $\mathrm{mm}$ in width and between entre 0,710 and $1,910 \mathrm{~mm}$ in thickness. The biggest dimensions are recorded at the origin of Matmata compared to others provenances.

The length of Matmata and Beni Khedache seed are the most important followed by Bou Hedma and low for Djerba. It's similarly to the width and thickness.

While mean seed length was 4,175 mm, seed width was 2,905 mm and thickness was 1,325 mm. Mean mass of the 100 seed was $4,874 \mathrm{~g}$. The range of variation of the average varies between 3,180 and 7,120 g. The range of variation of average sphericity of the seed varied between 0,510 and 0,660 which mean seed sphericity was 0,604 .

Geometric and arithmetic diameter seed were between 1,950 - 2,940 $\mathrm{mm}$ and 2,480 - 8,490 $\mathrm{mm}$ respectively. The surface area ranged between 11,980 and $27,170 \mathrm{~mm}^{2}$. Mean fruit volume was $118,742 \mathrm{~mm}^{3}$. A highly significant difference between and within the site $(0,000<0,05 \%)$ was found on the results of the ANOVA (table 2). table 3 .

The correlation matrix between properties of Rhus tripartitum fruits in the different origins is carried in

Table 3. Correlation matrix between analyzed dimensions and geometric properties of Rhus tripartitum fruits and seeds in the different origins

\begin{tabular}{|c|c|c|c|c|c|c|c|c|c|c|}
\hline & & Lfr & Ifr & Efr & Dgfr & $\phi f r$ & Sfr & vfr & $\begin{array}{c}\text { Pd 100 } \\
\text { fr }\end{array}$ & Dafr \\
\hline \multirow{9}{*}{ Fruits } & Lfr & 1 & & & & & & & & \\
\hline & lfr & 0,841 & 1 & & & & & & & \\
\hline & Efr & $-0,129$ & $-0,026$ & 1 & & & & & & \\
\hline & Dgfr & 0,886 & 0,923 & 0,255 & 1 & & & & & \\
\hline & $\phi f r$ & $-0,789$ & $-0,425$ & 0,579 & $-0,419$ & 1 & & & & \\
\hline & Sfr & 0,88 & 0,925 & 0,257 & 0,999 & $-0,41$ & 1 & & & \\
\hline & vfr & 0,995 & 0,853 & $-0,143$ & 0,883 & $-0,775$ & 0,879 & 1 & & \\
\hline & Pd 100 fr & 0,446 & 0,476 & $-0,358$ & 0,335 & $-0,407$ & 0,341 & 0,475 & 1 & \\
\hline & Dafr & 0,873 & 0,927 & 0,26 & 0,997 & $-0,399$ & 0,999 & 0,873 & 0,347 & 1 \\
\hline \multirow{10}{*}{ Seeds } & & Lsme & Isme & Esmc & Dgsme & $\phi s m c$ & Ssme & Vsme & $\begin{array}{c}\text { Pd } 100 \\
\text { smc }\end{array}$ & Da smc \\
\hline & Lsme & 1 & & & & & & & & \\
\hline & lsme & 0,865 & 1 & & & & & & & \\
\hline & Esmc & 0,529 & 0,317 & 1 & & & & & & \\
\hline & Dgsmc & 0,843 & 0,707 & 0,886 & 1 & & & & & \\
\hline & $\phi s m c$ & 0,081 & $-0,006$ & 0,812 & 0,566 & 1 & & & & \\
\hline & Ssmc & 0,839 & 0,706 & 0,887 & 0,999 & 0,572 & 1 & & & \\
\hline & Vsmc & 0,975 & 0,847 & 0,641 & 0,908 & 0,23 & 0,911 & 1 & & \\
\hline & Pd 100 smc & 0,1 & 0,166 & 0,138 & 0,169 & 0,1 & 0,154 & 0,073 & 1 & \\
\hline & Da smc & 0,833 & 0,703 & 0,885 & 0,994 & 0,575 & 0,999 & 0,911 & 0,138 & 1 \\
\hline
\end{tabular}

We can confirm the existence of a very highly significant correlation between the geometric variables of the fruits of Rhus tripartitum. 
The examination of the matrix of simple correlation coefficients between the different parameters measured at the threshold of $5 \%$ risk highlights strong positive correlations $(0,841$ to 0,999$)$ between characters: Length fruit (Lfr), width fruit (lfr), geometric diameter of fruit (Dgfr), fruit surface (Sfr), volume of fruit (Vfr) and arithmetic diameter (Dafr).

Concerning the weight of 100 fruit character is positively correlated with the different characters and especially with the width and volume of fruit. While the Sphericity ( $\phi \mathrm{fr}$ ) is positively correlated with the thickness of fruit (Efr).

The correlation matrix between morphological characters of seeds is carried in table 3 .

The analysis of this matrix reveals positive correlations. The strongest positive correlation (0.703 to 0.999) was obtained between the morphological characters of seeds (Lsmc, lsmc, Da smc, Ssmc, Vsmc and Dg). This suggests the existence of a synergy between them. The correlation matrix of variables shows other weaker positive correlations $(<0,703)$ between (Lsmc and Esmc); ( $\$$ smc with Dg smc Dasmc and Ssmc). The lowest correlation was observed $(0,073)$ between the weight of 100 seeds and volume (Vsmc).

-Fruit color : fruit color varies from green before maturation (December-January) to bright red (early maturity= February). It joined the maroon to brown (full maturity = end of March) and dissemination (month of May) (Fig. 2).

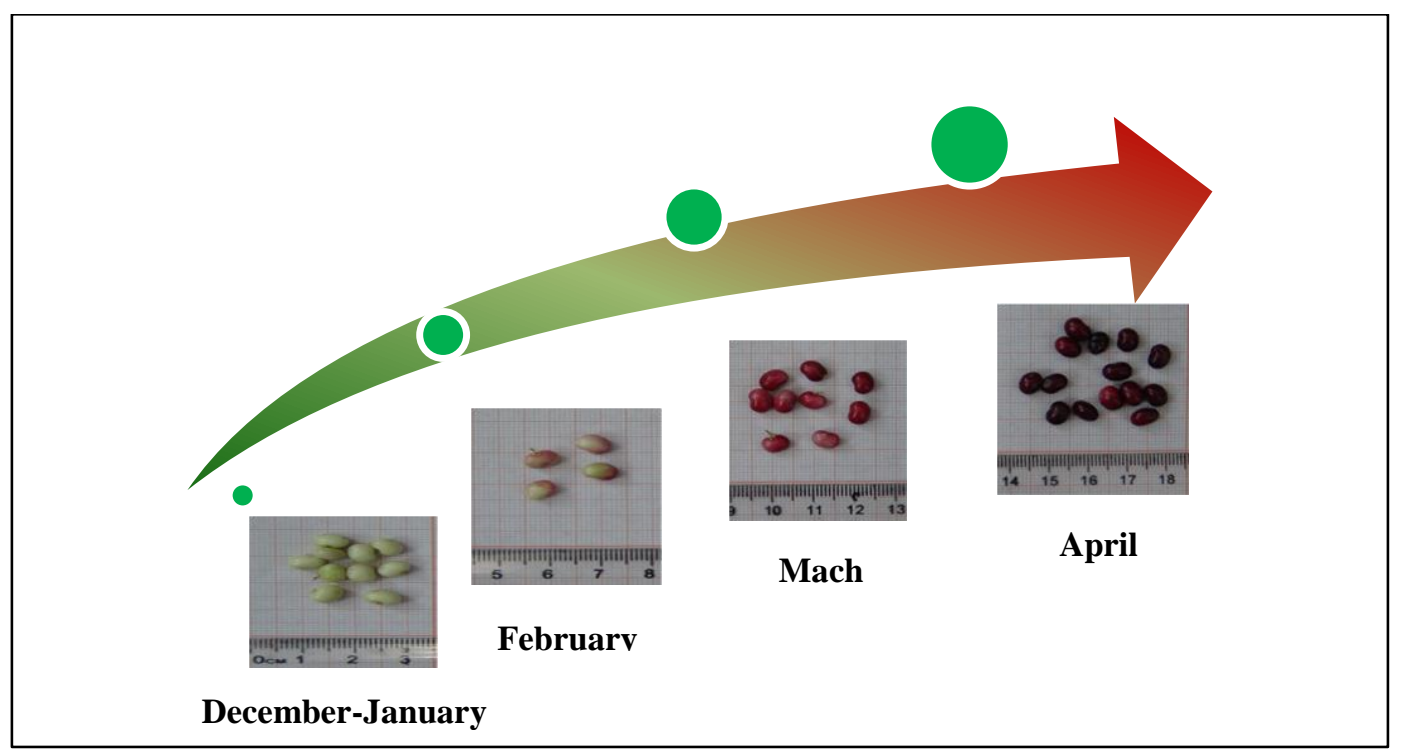

Figure 2. Different physiological stages of maturation of Rhus tripartitum fruit

Rhus tripartitum is a species mature winter and spring loop cycle. It is characterized by an apparent heterogeneity in the maturation stage. The shrub appears as a mosaic of color. We just collect the different colors of ripening drupes at the same time on the same footing Rhus tripartitum but with a variation of their percentage.

-Seed color : seed color Rhus tripartitum is yellow to brown.

-Classification of Rhus tripartitum provenances: the classification is based on geometric properties of fruit and seeds.

The dendrogram (Fig. 3) illustrates the relationship between provenances collection of fruits and seeds of Rhus tripartitum.

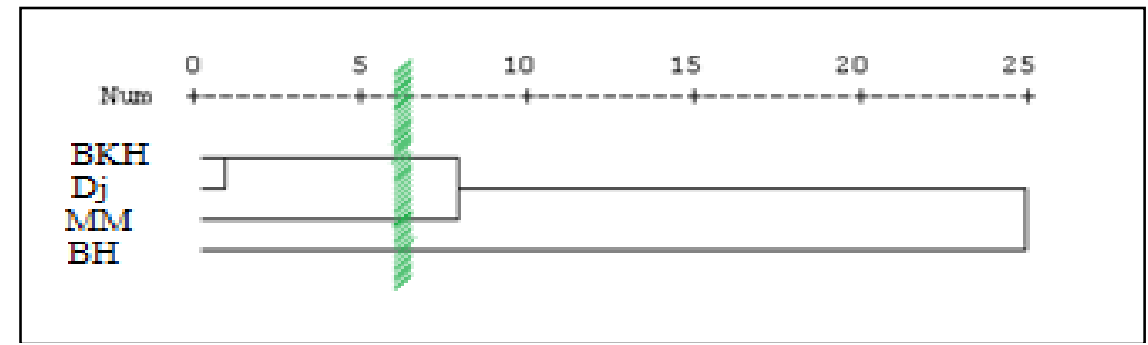

Figure 3. Relations between provenances of Rhus tripartitum (BKH): Beni khedache ; (Dj): Djerba ; (MM): Matmata and (BH): National Park from Bou Hedma 
It allows to distinguish three groups:

-Group 1: includes seeds and fruits from the two regions Beni khédèche $(\mathrm{BKH})$ and Djerba $(\mathrm{Dj})$.

-Group 2 : represented by the area from Matmata (MM).

-Group 3: represented by the National Park from Bou Hedma (BH).

\section{Conclusion}

Rhus tripartitum fruits and seeds shows that there is an inter-site variability observed between provenance. It is related to the phenotypic characteristics which may be due to the genetic effect. Any time you can assume some variability in the ability to adapt to environmental conditions. This is a species that requires high altitudes.

\section{References}

[1]. -Serville Y. (1984). Valeur alimentaire des aliments du 5e et 6e groupe, in : Tremolieres J.,ServilleY., Jacquot R., Dupin H., Manuel d'alimentation humaine, Tome 2 : Les Aliments », Tec \& Doc Éd., Paris, France, pp. 291-310.

[2]. -Parcesio J., Rafeces M., Castellote A. I., Codony R., Farran A., Garcia J., Lopez A., Romena A., Boatella J. (1995). Influence of variety and geographical origin on the lipid fraction of hazelnuts (Corylus avellena L.) from Spain: II.Triglyceride composition. Food Chemistry. $30: 245-249$.

[3]. -Pershern A. S., Breene W. M., Lulai E.C. (1995). Analysis of Factors influencing lipid oxidation in hazelnuts (Corylus sp.). Jourral of Food Processing and Preservation. 19 : 9-25.

[4]. - -Pala M., Açkurt F., Löker M., Yıldız M., Ömero ־glu J. (1996). Fındık çes, itlerinin biles,imi ve beslenme fizyolojisi açısından

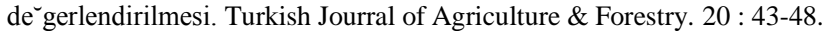

[5]. -Alphan E., Pala M., Açkurt F. et Yılmaz T. (1996). Nutritional composition of hazelnuts and its effects on glucose and lipid metabolism. Acta Harticulturae. $445: 305-310$.

[6]. -Besançon P. (1990). Besoins alimentaires et qualité nutritionnelle des aliments, in : Introduction à la biochimie et à la technologie des aliments, Tec \& Doc Éd., Paris, France, pp. 87-134.

[7]. -Hopkins W.G. (2003). Physiologie végétale : révision scientifique de Chales-Marie Evardad, p 66-68.

[8]. -Olajide J.D. et Igbeka J.C. (2003). Some physical properties of groundnut kernels. Journal of Food Engineering. 58: 201-204.

[9]. -Mirzabe A. H., Khazaei J., Chegini G. R., Pour M. H. A., Nejad R. (2013). Determination of some physical properties of virgin olive fruits. Agric Eng Int: CIGR Journal. 15(1): 201-210.

[10]. -Nazari Galedar M., Tabatabaeefar A., Jafari A., Sharifi A., O’Dogherty M.J., Rafee S. et Richard G. (2008). Effects of moisture content and level in the crop on the engineering properties of alfalfa stems. Biosys. Eng., 101(2): 199-208.

[11]. -Ozan M. et Haciseferogullari H. A. (2004). Condiment [Sumac (Rhus coriaria L. )Some physico-chemical properties. Bulg.J.Plant Physiol. 30 (3-4): 74-84.

[12]. -Kibar H. and Ozturk T. (2008). Physical and mechanical properties of soybean. International. Agrophysics, 22: 239- 244. 